\title{
Discursive Manoeuvres and Hegemonic Recuperations in New Zealand Documentary Representations of Domestic Violence
}

\author{
By \\ Carolyn Michelle \\ Convenor, Women's and Gender Studies \\ Department of Sociology and Social Policy \\ University of Waikato \\ Private Bag 3105 \\ Hamilton \\ New Zealand \\ Telephone:+64 78384847 \\ Fax:+64 78384654 \\ Email: c.michelle@waikato.ac.nz \\ And \\ C. Kay Weaver \\ Director, Bachelor of Communication Studies \\ Department of Management Communication \\ Waikato Management School \\ University of Waikato \\ Private Bag 3105 \\ Hamilton \\ New Zealand \\ Telephone: +64 78384466 X6222 \\ Fax: + 6478384358 \\ Email: ckweaver@waikato.ac.nz
}




\section{Carolyn Michelle and C. Kay Weaver: Biographical note.}

Carolyn Michelle is a Lecturer in the Department of Sociology and Social Policy and Convenor of the Women's and Gender Studies Programme at the University of Waikato, New Zealand. She has published work on the public communication of domestic violence, soap opera, and advertising representations of women. Her research interests include modes of audience reception of television and film, discursive negotiations around femininity, motherhood, and the family, and assisted reproductive technologies.

C. Kay Weaver is a Senior Lecturer in the Department of Management Communication and director of the Bachelor of Communication Studies at the University of Waikato, New Zealand. Her publications include (with Philip Schlesinger, R. Emerson Dobash and Russell P. Dobash) Women Viewing Violence (British Film Institute, 1992) and (with Cynthia Carter) Violence and the Media (Open University Press, 2003). Her current research projects include two New Zealand Foundation of Research, Science and Technology funded investigations, 'The socio-economic impacts of information communication technologies' and 'The socio-economic impacts of biotechnologies'. 


\title{
Discursive Manoeuvres and Hegemonic Recuperations in New
}

\section{Zealand Documentary Representations of Domestic Violence}

\begin{abstract}
This paper examines three television documentaries--entitled Not Just a Domestic (1994), Not Just a Domestic: The Update (1994), and Picking Up the Pieces (1996)--that together formed part of the New Zealand police 'Family Violence' media campaign. Through a Foucauldian, feminist poststructuralist discourse analysis, the paper examines how these texts assert and privilege particular understandings of domestic violence, its causes, effects and possible solutions. The analysis illustrates the way in which five discursive explanations of domestic violence--those of medical pathology, romantic expressive tension, liberal humanist instrumentalism, tabula rasa learning and socio-systematic discourse--are articulated and hierarchically organised within these documentaries, and considers the potential hegemonic effects of each text's discursive negotiations. It is argued that the centrality of personal 'case studies' and the testimonies of both battered women and formerly violent men work to privilege individualistic rather than sociopolitical explanations of domestic violence. Additionally, the inclusion of extensive 'survivor speech' means that women are frequently asked to explain and rationalize their actions as 'victims' of domestic violence, while fewer demands are placed on male perpetrators to account for their violent behaviour. Consequently, the documentaries leave the issue of male abuse of power largely unchallenged, and in this way ultimately affirm patriarchal hegemonic interests.
\end{abstract}




\section{Discursive Manoeuvres and Hegemonic Recuperations in New Zealand Documentary Representations of Domestic Violence}

Media representations of violence against women have raised considerable concern among feminist scholars. Such depictions have been critiqued for presenting women's victimisation as entertainment (Deborah Cameron and Elizabeth Fraser 1987; Lisa Cuklanz 2000; Keith Soothill and Sylvia Walby 1991), for normalising violence against women (Helen Benedict 1992; Cynthia Carter 1998), and for heightening women's fear of crime (Margaret Gordon and Stephanie Riger 1989; C. Kay Weaver 1998; C. Kay Weaver, Cynthia Carter and Elizabeth Stanko 2000). To date, however, analyses of representations of violence against women have predominately focused on acts of sexual violence committed against women by male strangers; largely as a result of the primary focus on stranger violence in both factual and fictional media content. ${ }^{1}$ As feminists have long argued, media largely neglect the more pervasive problem addressed in this paper-that of physical and/or psychological violence against women in the home--which most often occurs at the hands of men with whom women have close familial or personal relations (see for example Susan Caringella-MacDonald 1998; Marian Meyers 1997; C. Kay Weaver, Cynthia Carter and Elizabeth Stanko 2000). As Maggie Wykes states, the fact that the "ideal family can be a dangerous place when it includes a father/husband figure is rarely addressed outside of feminist academia" (1998: 236).

In those fewer instances where the media have reported on cases of domestic violence, the nature of the coverage has also been heavily critiqued. Investigations of US 
news reporting conclude that domestic violence is typically portrayed as the problem of aberrant men, and as the result of individual behavioural flaws or pathologies (Wendy Kozol 1995; Mary McDonald 1999). Examining domestic violence in reality television shows such as Cops, Dianne Cyr Carmody (1998) and Mia Consalvo (1998) suggest that the causes of domestic violence are typically presented in simplistic and singular terms, with the violence attributed to individual dysfunction, the batterer being drunk and angry, the volatile 'nature of love', poverty, and irrationality, passivity and even masochism on the part of victims. Consalvo (1998), for example, notes that in $\underline{\text { Cops, }}$, recurring violence is frequently attributed to the failure of victims to 'simply' follow police advice and press charges, leave the violent context, or throw their abuser out. In this respect, programmes typically support 'victim-blaming' understandings of domestic violence (Carmody 1998) by implying that the crime is easily solvable, if only victims would act more sensibly and responsibly.

The tendency of media to represent the issue of domestic violence in individualistic terms has also been documented. Kozol (1995: 648) notes that US news stories typically focus "on the women involved, either blaming them for the abuse or championing them as lone heroines fighting lone villains”. Nancy Berns (1999) also argues that mainstream media representations, while often sympathetic to women's experiences, have become increasingly victim-centred and most often portray domestic violence as the private, personal problem of women victims. Thus, domestic violence is presented within an individual frame of responsibility, which posits 'the problem' as lying with those directly involved--the victim, batterer, or couple--and thus focuses on personalised solutions such as counselling or separation. As Berns (1999) notes, it is exceedingly rare for domestic 
violence to be presented in terms of an institutional frame of responsibility, wherein fault is attributed to the police and legal or medical establishments, which are often in a position to intervene but frequently fail to do so. Lisa McLaughlin (1998) has also identified how, even in high profile cases of domestic violence (such as OJ Simpson's alleged murder of his ex-wife Nicole Brown Simpson) the actual crime of domestic violence is likely to be downplayed or trivialised. Kozol (1995) also criticises the tendency for domestic violence to be presented as a 'private trouble' rather than a serious political issue, and believes this may marginalize feminist socio-cultural explanations linking male violence against women to a legacy of male power and dominance in patriarchal societies (see also Mary McDonald 1999).

Given feminist critiques of media representations of domestic violence, and more especially the media's often noted lack of attention to this issue, it has been a matter of particular interest to us that the past decade has seen domestic violence feature in a surprisingly large number of New Zealand films and television broadcasts, including the feature film Once Were Warriors (1994), the long-running soap opera Shortland Street, and at least five documentaries entirely devoted to exploring violence against women in the home. Two further documentaries on child abuse have also been broadcast; along with two separate television advertising campaigns targeting violence in the home.

That domestic violence has featured with such regularity on New Zealand television can be partly explained by political and institutional concerns about the broader effects of this violence. Over the last twenty years, social and governmental agencies have periodically highlighted the need to drastically reduce the incidence of domestic violence in New Zealand, not only to prevent the suffering it causes, but also because it is seen as 
having other significant social and economic costs. Domestic violence constitutes around eighty percent of all violence reported to the police in New Zealand, and the vast majority of this violence comprises adult men assaulting women and children (Damian O'Neill 2000: 2). It was estimated in 1994 that in terms of police, judiciary and welfare time and resources, domestic violence may cost New Zealand up to $\$ 5.302$ billion each year (Susan Snively 1994: iv) What is more, clear connections have been made between domestic violence and other violent crime in New Zealand, with the Department of Social Welfare declaring that violence in the home constitutes "the cradle for the perpetuation of violence in the community" (1996: 5).

It was within this context of heightened concern about the individual and societal effects of domestic violence that senior police personnel developed a national media campaign to raise public awareness of what they termed 'family violence" as a criminal offence; one that should be brought to the attention of the police so that victims might be better protected and perpetrators brought to justice. This campaign message was mediated through two series of television advertisements and two music videos (with accompanying audio cassettes). The core campaign message 'family violence is a crime' also featured on materials such as pens, posters and billboard hoardings. In addition, the police, in conjunction with the Auckland production company Communicado, secured funding from New Zealand $\mathrm{On} \mathrm{Air}^{3}$ and broadcasting agreements from TVNZ for the three television documentaries, each focusing on 'family violence' and police initiatives to combat this crime.

The police media campaign was originally intended to run for a five-year period (1994-1999), but due to lack of funding was terminated in 1997 (for further discussion, 
see Weaver and Michelle 1999). Nevertheless, to date it remains the most comprehensive New Zealand media campaign aimed at preventing domestic violence. Furthermore, the three documentaries and advertisements remain available from the New Zealand police, who have promoted their use in counseling programmes and in schools, where they continue to feature as part of the year 11 English curriculum in some areas. Additionally, police personnel involved in the campaign have provided formal advice to police forces in the South Pacific, the USA and Britain on creating their own campaigns addressing domestic violence.

Given that this campaign has been, and indeed remains, influential in framing understandings of domestic violence in New Zealand and elsewhere, it is important to consider how the campaign materials represent the issue and encourage audiences to make sense of male violence against women. In this paper then, we specifically focus on the discursive representation of domestic violence in the three police documentaries, entitled Not Just a Domestic (1994), Not Just a Domestic: The Update (1994), and Picking Up the Pieces (1996).

\section{Theoretical perspective for the documentary analysis}

Our analysis of the three documentaries follows a critical media studies approach, in which the mainstream media are regarded as playing a major role in providing the discursive frameworks through which we can interpret issues and make sense of our own and other people's experiences (John Corner, Kay Richardson and Natalie Fenton 1990; Greg Philo 1990). Specifically we use a mode of Foucauldian, feminist poststructuralist 
discourse analysis that proceeds from Michel Foucault's (1972 and 1980)

reconceptualisation of language use as discursive.

Briefly, Foucault (1980) describes discourses as socially and historically specific, changeable and competing ways of constructing knowledge. Grounded in different assumptions about the nature of 'reality' and representing different values, beliefs and interests, discourses "systematically form the objects of which they speak," (Foucault 1972: 49) in the sense of defining and delimiting how these objects are understood and talked about, and by whom (Michel Foucault 1980; Chris Weedon 1987). While some discourses are essentially compatible and mutually reinforcing, others are at odds and must struggle against each other to assert their particular knowledges and gain hegemonic ascendancy (Normal Fairclough 1989; Ernesto Laclau and Chantal Mouffe 1985). When a particular discursive position achieves dominance, it comes to assert a certain set of concepts or practices as the natural and legitimate way of thinking and acting in the world (Fairclough 1989; Foucault 1980; Weedon 1987).

This notion of discursive contestation and struggle between competing 'regimes of truth' (Foucault 1980) is central to our analysis of the documentaries. We concur with McDonald, who asserts that "representations of battering take on an additional function as significant sites where larger cultural understandings of domestic violence are constructed, contested, and struggled over" (1999: 112-3). We thus regard these texts as active participants in a wider struggle to assert particular discursive understandings of domestic violence within the public domain.

Our understanding of this wider discursive field draws on Damian O'Neill's (1998 and 2000) insightful work delineating the five predominant discourses structuring 
research and theory on domestic violence within the social sciences, and thus potentially available to both experts and laypersons in constituting their understandings of this 'object of discourse'. Outlined in greater detail below, these include the discourses of medical pathology, romantic expressive tension, liberal humanist instrumentalism, socialsystemic discourse and tabula rasa learning (O’Neill 1998 and 2000). While not an exhaustive account — marginalized perspectives very likely circulate alongside these more prevalent discursive 'voices'--we believe O’Neill's schema offers a very useful framework for the development of media analyses of representations of domestic violence.

The discourse of medical pathology constructs domestic violence as atypical or aberrant behaviour, and as symptomatic of some other underlying psychological disorder or illness. Among the possible 'causes' cited in the research are various mental and personality disorders thought to generate difficulty in controlling anger (Richard Gelles 1999; Damian O’Neill 1998), alcoholism and drug abuse (Glenda Kaufman and Murray Straus 1990; Theresa Zubretsky and Karla Digirolamo 1996), relationship dysfunction and even victim precipitation, including the 'masochism thesis' (Jane Caputi 1992). Others suggest that violence in adulthood may stem from an abusive childhood, and can be transmitted intergenerationally in a 'cycle of violence' (Richard Gelles and Murray Straus 1988; Lenore Walker 1989). Linking these diverse theories is their attribution of causality to some specific pathology or disorder that particular individuals suffer from, and which requires a treatment or cure (O’Neill 1998). Abusers are thereby positioned as sick individuals who need help rather than condemnation. 
Somewhat differently, the discourse of romantic expressive tension suggests that domestic violence is a manifestation of very high levels of tension or frustration that build up inside individuals in a natural response to specific stressors--such as unemployment, problems at work, lack of education or life skills, and relationship conflict (Gelles 1999; O'Neill 1998 and 2000). The build up of tension and frustration eventually becomes so great that the individual snaps, producing an explosion of wild, uncontrollable rage that gets misdirected at a comparatively 'safe' target--weaker family members within the 'private' domestic realm (O’Neill 2000).

In stark contrast, the discourse of liberal humanist instrumentalism constructs domestic violence as intentional, goal-directed behaviour that is used by rational, conscious agents as a means to obtain a particular end--to win an argument, get one's own way, punish someone, or assert control over them (O'Neill 1998). In similar terms, the feminist instrumentalist perspective contends “battering arises out of men's need and desire to use power and coercive control with their partners" (Gelles 1999: 41). As Rebecca Dobash and Russell Dobash assert, men's “violence is often used to silence debate, to reassert male authority, and to deny women a voice in the affairs of daily life" (1998: 153). From this perspective, far from being out of control, violent men are fully responsible for their actions and aware of its effects.

Differently again, the discourse of tabula rasa learning asserts the behaviourist view that domestic violence is a learned response unwittingly derived from observation, experience and conditioning--particularly in terms of gender socialisation and family role modelling--and frequently reinforced within dysfunctional adult relationships ( $\mathrm{O}^{\prime} \mathrm{Neill}$ 1998). In terms of this discourse, violent responses are naturalistically acquired as part of 
the perpetrator's 'behavioural repertoire' (Albert Bandura 1973, cited in Damian O’Neill 1998), and certain proponents suggest that both violent men and their partners need help to 'unlearn' the destructive patterns of behaviour they have collectively acquired.

Finally, socio-systemic discourse constructs men's domestic abuse of women as “a logical extension of various cultural norms and institutional practices in western society" (O’Neill 1998: 8). These pre-existing norms, values and practices are instilled through gender socialisation, which conditions boys to become aggressive, 'tough', dominant, and in control, while girls are socialised to be passive and to sustain dysfunctional and even violent relationships. In these terms, male violence against women is conceived as "an outgrowth of male power and privilege" and "reflective of a larger patriarchal structure that functions to subordinate women” (Amy Marin and Nancy Russo 1999: 20). Proponents of this discourse typically perceive violent men as in need of re-education or consciousness raising, and advocate initiatives such as educational media campaigns and mandatory arrest policies (O’Neill 1998).

This schema of the predominant discourses circulating within the wider public domain comprises the framework through which we approached our analysis of how domestic violence was constructed by the documentary presenters and the victims, perpetrators, witnesses and 'expert' commentators featured. We examined each documentary in terms of its format, visual articulation, narrative structure, key themes, and the discursive perspectives articulated by different speakers. We also investigated how the textual struggle to assert and privilege particular understandings of domestic violence relates to wider socio-political struggles to define domestic violence, its causes, consequences, and possible solutions. In effect, we sought to make visible the discursive 
manoeuvres occurring within each documentary--specifically in terms of how domestic violence is represented and which discursive meanings are privileged, marginalized, and/or recuperated in the process--and also sought to highlight the potential hegemonic effects of these textual negotiations.

\section{Documenting domestic violence in New Zealand}

Each documentary was between thirty-nine and forty-five minutes in length and screened during prime time on New Zealand's most watched national television channel, TVOne. Not Just a Domestic is presented by Andy Anderson, known for playing 'macho' characters in New Zealand film and television fiction, and features the case studies of four couples whose relationships have been marred by domestic violence; Richard and Vivian, Peter and Trish, Kathryn and David (both deceased), and Joe and Awhi. Also featured are Christine and Terrie--both survivors of domestic violence--and 'expert commentators' from Men for Non-Violence, Women's Refuge, and the police.

Not Just a Domestic: The Update was presented by Temuera Morrison, who played the brutally violent character Jake Heke in the movie Once Were Warriors (1994). This programme follows up the situations presented in the first documentary by revisiting eight of the individuals involved--Terrie, Christine, Joe and Awhi, Richard and Vivienne, and Peter and Trish. Dramatisations of the procedures for arresting and processing domestic violence offenders also feature, along with several new 'real life stories' recounted by victims, as well as former perpetrators and witnesses--Martha and Robert, MP Ruth Dyson, Bede, Jim, Daniel, and Paratene. Also included are brief extracts from interviews with 'experts' and officials from the police and judiciary, Women's Refuge 
and its parallel organisation, Maori Women's Refuge, and various men's groups such as Men For Change. This documentary places considerable emphasis on how the participants' lives have altered for the better, and also stresses the capacity of violent men to change. This desire to specifically address--or at least, avoid alienating--men in the audience was key factor in the choice of Andy Anderson and Temuera Morrison as presenters, as the executive producer of both documentaries explains: "it was simply a matter of having a bloke talking to blokes, basically". ${ }^{4}$

In both Not Just a Domestic and The Update, over two-thirds of the programme time consists of extracts from interviews with those featured in various case studies of domestic violence. This is more than twice that spent on 'expert' commentary, presenter discussion and/or voice-overs. Consistent with the interactive mode of documentary articulation described by Bill Nichols (1991), the location of textual authority thereby shifts away from the author/producer and comes to reside in the authentic 'social actors' featured in each programme - the 'real' victims, perpetrators and witnesses — whose selfrevelations, comments and responses effectively present the textual argument. Where 'experts' and presenters do feature, their commentary generally serves to reiterate the textually preferred modes of response by both victims and perpetrators--either calling the police, or seeking help from an appropriate support service. Thus, a key message of both $\underline{\text { Not Just and Domestic and The Update is that of seeking intervention as a catalyst for }}$ change, and this message is articulated by a succession of witnesses who attest to its essential truth. 
The third documentary, Picking Up the Pieces, continues in an interactive mode but moves away from the earlier case study mode of presentation by excluding all 'expert' commentary. This programme relies almost entirely on the personal accounts of three battered women--the presenter/victim Marg Dixon, Barbara, and Christine--along with two men, Matthew and Bob, who each witnessed their mother being assaulted by a male partner. Picking Up the Pieces also differs in explicitly highlighting the negative effects of domestic violence on children, both as victims and witnesses of abuse. Its core message is articulated in Marg Dixon's introductory statement: "When adults fight, children get hurt too. Hearing or seeing violence can be as damaging for children as being abused themselves."

Another divergence in this documentary is its partial use of a mode of presentation that Myra Macdonald (1998: 114) describes as 'testimony,' in which subjectivity becomes explicitly legitimated as a basis of knowledge. The presenter is herself a Women's Refuge worker, and her opening statements position her as both a child witness to her father's violence, and as subsequently victimised by an abusive husband. Dixon is frequently positioned as the privileged voice of personal experience in the programme, and often makes connections between her own experiences and the issues being explored. At one key moment, the tables are explicitly turned when she is recast in the role of interviewee, and is asked by Barbara to relate her own experience of domestic abuse and the circumstances that led to her seeking help. Linda Alcoff and Laura Gray (1993) argue that such a strategy has considerable transgressive potential, since it effectively destabilises the usual hierarchy between 'objective' authoritative knowledge (as typically embodied by documentary presenters), and the subjective experiential knowledge of 
those more often constructed as the objects of speculative gaze. However, as Macdonald (1998) also notes, the transgressive potential of personal testimony (and hence also survivor speech) can become constrained in situations where there is a lack of selfreflexivity about its use, since experience becomes treated as a fixed and ultimately stable basis for knowledge production.

The centrality of personal testimony in all three documentaries, and particularly Picking Up the Pieces, also needs to be considered within the context of an emerging trend toward greater 'intimization' (Liesbet van Zoonen 1991: 217) in the documentary genre. This trend privileges the spectacle of intimate revelation and the personalisation of social issues over the in-depth discussion and 'objective' analysis that formerly comprised the hallmark of 'serious' documentary programming (Macdonald 1998). As noted by Alcoff and Gray, the "emotional 'shock value"" of such representations constitutes a recuperation of feminist attempts to 'break the silence' around these issues, by way of eroticising "the depictions of survivors and of sexual violence to titillate and expand [television] audiences" (1993: 262). Significantly, Macdonald suggests that commodification of women's experiences of violence may have considerable appeal to documentary makers in particular, as they are increasingly "searching for novelty and besieged by the need to increase ratings" (1998: 120). Macdonald's assertions are especially poignant in the context of the funding and broadcasting of the three documentaries considered here. Each was funded by New Zealand on Air, which only funds projects with a secured guarantee of screening from a broadcaster. This guarantee was given by Television New Zealand, but on condition that the content of each documentary would have general appeal to a wide audience, so as to ensure high ratings 
and thus be attractive to advertisers. Such commercial imperatives undoubtedly affected the discursive mediation of domestic violence in all three documentaries. (Further discussion of the impact of commercial sponsorship on the police family violence campaign can be found in Weaver and Michelle 1999).

\section{Discursive manoeuvres in the documentary representations}

Each of the five discourses around domestic violence identified by O'Neill (1998 and 2000) and outlined above is indeed present (to differing degrees) in one or more of the documentaries. They are, however, organised hierarchically, in the sense that the selection of material for inclusion and its editing and (visual and linguistic) framing within the context of a wider narrative structure systematically works to privilege certain discursive understandings over others. The discursive manoeuvres involved in this process can be observed in a number of areas, but perhaps most immediately in the language used to refer to the issue of domestic violence from the outset.

Judging by the titles of the first two documentaries--Not Just a Domestic and Not Just a Domestic: The Update--one might assume they are underpinned by socio-systemic discourse, since the phrase Not Just a Domestic appears to explicitly challenge public tolerance and normalisation of men's domestic abuse of women and children. However, within the context of the police campaign as a whole, this challenge is effectively suppressed by the nomenclature used in campaign materials, and specifically by the use of the descriptor "family violence". This discursive manoeuvre effectively silences feminist instrumentalist and socio-systemic analyses of the connection between domestic violence and male power, by masking the fact that "abusers are typically men who act 
violently against women and children" (Kozol 1995: 657). Given that women remain seven to ten times more likely to be seriously injured as a result of intimate partner violence (Straus and Gelles 1990), failing to specifically identify men as the major perpetrators of violence in the home and women as their predominant victims has important political implications.

Our analysis also suggests that the use of such nomenclature in the police campaign served to exonerate violent men. This exoneration occurs through the consistent tendency of these texts to conflate and privilege the discourses of medical pathology, romantic expressive tension and tabula rasa learning, a process which serves to displace and silence the more critical accounts offered by liberal humanist instrumentalist and sociosystemic discourses. As a result, all three texts repeatedly imply that abusers have diminished responsibility, since their violence is 'caused' by--alternatively--an underlying pathology, uncontrollable internal forces, or behavioural patterns unwitting acquired through life experience. Violent men are further exonerated through the overwhelming textual focus on personal narratives and the resulting location of specific causal factors in the personal histories of individual victims and perpetrators.

Just one of many examples from the documentaries serves to illustrate this process. Early on in Not Just a Domestic viewers are introduced to Richard, who initially articulates liberal humanist instrumentalist discourse when acknowledging his past deliberate use of violence to "get his own way" and punish weaker family members, including his daughter and wife Vivian. However, as Richard's story unfolds, the editing, script and narrative structure all gradually reframe his violence through the discourses of medical pathology and tabula rasa learning by relocating the causes of his behaviour in 
external historical factors falling outside his control. This process is evident in the scripted commentary of Andy Anderson, which is almost immediately followed by Richard's confirmation of the alternate 'reading' of causality now being proposed: Andy Anderson: [It] wasn't so easy for [Richard] to face up to the unhealthy behaviour he'd shown to his wife and family. In counseling, he learned how patterns of violent behaviour can develop.

Richard: I certainly recall some very severe hidings, with straps and numerous wooden spoons being broken across my backside or my legs. I can see patterns that I repeated. (Our emphasis)

As Richard relates his childhood experience to an off-camera interviewer in mid closeup, we cut to various black and white photographs of him as a child with his brothers and mother. These dissolve to an adult Richard in full colour, immediately followed by recent live footage of Richard at work, just as he speaks of repeating patterns learned as a child. In this way, both the visuals and dialogue affirm the connection between past experience and present day behaviour and Richard is consequently repositioned, not as a dominating and oppressive agent within his family, but as himself suffering from some kind of dysfunction and hence driven to repeat 'unhealthy' patterns acquired during his own childhood experience of parental abuse. This conflation between the discourses of medical pathology and tabula rasa learning also offers a new, more desirable subject position, which Richard readily assumes--that of the 'sick abuser' requiring our sympathy and help--as evident in his subsequent lament: "I only wish now that I'd gone and sought real help earlier, so that I didn't lose the one person that I wanted the most." In this way, 
Richard's responsibility for his violence is partially absolved, and he is reconstituted in almost childlike form as a passive and unwitting victim--yet another casualty of the intergenerational 'cycle of violence'.

The implicit discursive exoneration of violent men also frames a key moment of The Update. Here, Temuera Morrison's scripted speech initially articulates the instrumentalist 'power and control' model: "All around New Zealand, anger management groups are getting to grips with the real reasons men are violent. It's about power and control." However, the political impact of this critique of male power is undermined by Morrison's next sentence, where he explains, "Violence is now seen as learned behaviour. Men have to learn new and non-violent behaviour." (Our emphasis). Thus, while male violence may be 'about power and control', such behaviour is simultaneously constructed as passively acquired rather than stemming from a conscious intent to use physical force to control and dominate women. In this way, the troubling suggestion that some men deliberately use violence to pursue particular ends is effectively silenced. In its place, this text privileges the tabula rasa learning position that violent men behave this way in response to external or contextual factors outside their direct control--such as an underlying pathology, a bad childhood, or acquired patterns of interaction--and hence are not entirely responsible for their actions.

At other moments in all three documentaries, the discourse of romantic expressive tension prevails in a way that positions abusers as engaging in uncontrollable acts of blind rage, and hence as not fully responsible for their actions. In the following extract from Picking Up the Pieces, for instance, Marg Dixon relates her own experience in precisely these terms to Barbara, who adopts the role of interviewer in this emotionally- 
intimate exchange, shot in a combination of long shot, mid close-up and close-up as the two women sit at a kitchen table:

He just went berserk, just took to me ... I was looking at his eyes, his eyes were just-gone ... He was so consumed with rage, I was like, 'look what you're doing', getting him to connect with me. And he was ... out to lunch ... I thought I was dead, because he was so out of control.

In certain key respects, the predominance of the personal case study and 'testimonial' modes of presentation in these documentaries also serves to marginalize socio-systemic accounts of men's domestic abuse of women in favour of more individualistic accounts. Such modes of presentation simultaneously deflect attention away from the connection between individual men's violence and the wider context in which relations between men and women have long been structured by an historical legacy of patriarchal power and control (Miranda Davies 1994; Rebecca Dobash and Russell Dobash 1979 and 1998). Rather than risk alienating (male) viewers by dwelling on such potentially controversial explanations, the editing and narrative structure of each documentary directs our attention toward an individual frame of reference and privileges the experiences, actions (and apparent inactions) of, for the most part, victims. This is particularly evident in relation to the question of 'Why do women stay?', which constitutes a central narrative dilemma of all three documentaries.

In responding to this question, the first two documentaries make passing reference to many women's fear of retribution should they attempt to leave, the social stigma against middle-class women talking about problems at home, many women's lack of independent finances, and power issues within the relationship. Such references appear to form part of 
an implicit, repetitious attempt to make rational sense of the apparent choice of many women to stay in a violent relationship. However, in the absence of a more coherent and sustained analysis of this complex issue, these documentaries potentially affirm highly problematic understandings of domestic violence in which abused women are held partly responsible for, and are seen to be colluding in, their own victimisation.

An example of this implicit affirmation of victim-blaming discourses can be seen in The Update, during a sequence in which Martha - shown in mid close-up sitting on a lawn--relates her experience of living with extreme and repeated acts of violence over several years. Martha's initial explanation articulates aspects of instrumentalist discourse in implicitly identifying the operation of a pervasive 'power and control' dynamic within her relationship:

I couldn't look at people and talk. Always had to have my head down . . . / . . couldn't even talk to women just in case they were talking about him. Friends stopped calling around, and he was more or less my only ... friend ... And the next day he'd say he loved me. That's not love--it's dominating. Like he had to have something to control; it ended up being me. And I let him.

Immediately following this account of the absolute control Martha's partner had over her-control clearly maintained by way of repeated and extreme physical and emotional violence--her story is interrupted by Temuera Morrison's scripted question: "Why does a woman keep on going back to such a violent man?" Thus, the narrative dilemma is posed in terms of how we might comprehend such (seemingly irrational) behaviour on the part of the victim. In effect, Martha is 'asked' by the text to justify her own actions and responses in terms of her ongoing 'failure' to escape the abuse. The focus of attention and 
responsibility consequently shifts away from her attacker, Robert, and his apparent need and social license to dominate and control his partner, and comes to reside instead with Martha. This focus on Martha's implied (and apparently assumed) culpability is subsequently reaffirmed as Morrison then proceeds to introduce her brother-in-law, Boxer Cook, who is said to have "rescued Martha before--too often for his liking". The brother-in-law explains:

Ten years ago I gave up helping her. I watched her lying in the bed with a smashed up face and pregnant nine months and things, and I just washed my hands of her ... [B] ecause soon as I get her right, her face heals up and things, [she says] 'I want to go back to [Robert]', and it starts all over again.

Here, Martha is constructed as something of a 'lost cause' whose actions seem entirely inexplicable. Robert's violence, on the other hand, evidently requires no particular explanation--since none is offered--and in this way becomes discursively naturalised.

This perennial question of why women stay in a violent relationship is explored in depth in Picking Up the Pieces. At one point, Barbara is asked by Marg Dixon, "How do you lose yourself to it, in an abusive relationship? What happens?'. The following (abridged) extract provides a useful example of precisely how an exclusive focus on the personal stories and emotional responses of those who have experienced or witnessed violence can simultaneously lend support to discourses ascribing women full or partial responsibility for their own victimization:

Barbara: I think it starts from when you lose your self-esteem and your confidence, and they seem to have this power over you. You think you're nothing without them, that they really do need you, that they really do love you ... [Y]ou forget that that's 
not love, but you think it is, and so you just keep trying ... I left and went back. Kicked him out, took him back ...

Marg Dixon: Did at any time he concede that his behaviour was out of order, or out of control?

Barbara: Oh yeah, yeah. But I think he just thought, for him, that was the norm ... 'If you love me, handle it. If you love me, do this.' ... [And I believed] that if I treated him like someone special, then he would become something different than what he was.

Here, Barbara is ascribed and indeed assumes partial blame for 'losing herself' to her partner's abuse, thereby absolving him of full responsibility for his violent behaviour. While Barbara receives absolution from Dixon as the presenter, her own words are effectively mobilized and deployed within the context of the wider narrative structure in a way that attributes to Barbara a degree of moral responsibility for the violence committed against her.

The prevailing focus on the actions of victims also serves at times to reaffirm cultural presumptions regarding women's moral responsibility for children, in terms of protecting them from potential harm. All three documentaries make an implicit (and at times explicit) association between women's failure to simply leave a violent relationship and the damaging effects on children of witnessing violence. The Update, for example, features the story of Matthew, who as a child saw his mother repeatedly assaulted by her then boyfriend. Matthew states:

One thing that I found hard was that every time it happened, after a period of time they'd be back together again ... I was trapped, I couldn't really help or do anything 
because my mother was my authority in a way and she kept going back to him. And really to me it was senseless. And I'd really plead for anyone out there to not just consider themselves . . . but also their children, friends and relatives even. It's not fair for a lot of people.

The implication here is that it is unfair and inconsiderate for a mother to 'collude' in her own victimization by going back to a violent man and thereby exposing her children to such an environment. Again, the primary focus is on the behaviour of the victim, rather than on the abusive and controlling tactics of the violent partner.

Women's moral responsibility for exposing children to violence is addressed at length in Picking Up the Pieces, through a series of personal narratives which either articulate the damaging affects on children of witnessing violence, or focus on women's attempts to explain why they stayed in a violent relationship, and how they finally took action to escape. Unlike the other two documentaries, no attempt is made to explain why some men are so brutally violent to those they claim to love. By virtue of this absence, women are effectively ascribed moral responsibility for exposing children to the direct and indirect effects of men's violence, whether or not they are themselves victims of similar abuse.

We would also argue that the privileged focus on personal narratives, along with the individualistic causal explanations of violence offered by these texts, at times worked to undermine the stated core messages of the police campaign as a whole. That is, domestic violence is consistently (re)presented as a private matter stemming from personal inadequacy and/or relationship dysfunction, as opposed to a public concern characterised by not just criminality, but also an abuse of male power. This textual process can be 
observed in the first two documentaries, wherein the preferred strategies of seeking help and changing behaviour are articulated alongside an equally strong narrative theme promoting the hope of future reconciliation between victims and offenders--an outcome at one point described by Temuera Morrison as a "fairy tale ending". The documentary makers and key police personnel were keen to promote this kind of reconciliatory conclusion. Indeed, when interviewed, a Police Inspector involved in overseeing the campaign stated: "[B]ack together ... working out well, this is great stuff, this is intervention as it should be. Yeah, we were really committed to that sort of hopeful outcome." The notion that with help, estranged partners can eventually be reconciled is expressed on several occasions, and clearly constitutes a privileged discursive understanding, especially in the first two documentaries.

Remarkably, this position is affirmed despite clear evidence of continued violence in two of the relationships featured. When Trish and Peter first featured in Not Just a Domestic, both spoke about how the exposure of Peter's violence led him to seek help from a men's group. As a result, the couple were able to "work things out". However, when revisited in The Update, it seems things had not been quite so easy. As Temuera Morrison explains, the couple are "still working hard at changing their patterns of behaviour." The scene, which features images of Trish and Peter smiling and happily chatting together outside their home before talking to the off-screen interviewer in closeup, updates viewers on the couples' current situation:

Temuera Morrison: [Voice-over] Peter was in court recently for giving Trish a swollen lip during a row. But he was discharged without conviction. The family's still together. And they've learnt a lesson. 
Peter: Basically ... we had a bit of a slip-up, it wasn't anywhere near as major as ... some of the so-called good old days ... But it's just something we've worked through and we've dealt with.

Trish: We had slipped back into the old routine ... we took each other for granted a bit too much probably.

Here, Trish is ascribed, and indeed assumes, partial responsibility for her husband's criminal assault, in a manner that is consistent with tabula rasa learning's behaviourist assertion that individuals and couples acquire (and can unlearn) dysfunctional modes of interaction. Peter's responsibility for his violence is thereby minimised and displaced as his 'minor slip-up' is discursively reconstructed as the result of their collective relationship failure, both parties being equally at fault for having 'taken each other for granted'. Alternative understandings of this violent incident are suppressed as the text works to uphold its privileged narrative theme regarding the possibility of successful change and reconciliation, with Peter and Trish positioned as exemplars.

But perhaps more problematic here is the lack of critique of the institutional failure reflected in Peter's discharge without conviction, despite clear evidence of an assault. That this admission passes without comment is consistent with the individual rather than institutional frame of responsibility in the documentaries, yet effectively undermines the core campaign message that 'family violence is a crime' for which offenders will (presumably) be punished. Instead, Peter's criminal assault is discursively (re)presented as 'just a domestic' after all. 
Towards the end of The Update, the narrative theme of reconciliation is again privileged despite evidence of continued abuse within a second relationship--that of Martha and Robert. Temuera Morrison explains that in this case, Martha decided to return to her violent partner:

What's more, they got married, here in the courthouse where he was due to appear later for assaulting Martha. He got a suspended sentence. Some of Martha's family predict the violence will resume.

Significantly, the question immediately posed by Morrison is not, 'Why does Robert get away with it?', but rather, 'Why has she gone back?'. Furthermore, despite the hinted-at fears for Martha's safety, the concluding scenes of this documentary actually feature various overt signifiers of domestic harmony and reconciliation, including photos of Martha and Robert placed side by side, shots of Martha laughing and Robert smiling, and visual scenes of the happy couple sitting together with their four children around the kitchen table. Any potential critique of the institutional failure evident in the suspension of Robert's sentence for an act of criminal assault is once again silenced and displaced by the privileging of reconciliation as the central narrative theme. Remarkably, the last words of any of those interviewed in The Update are those of Martha's now supposedly 'reformed' husband:

Robert: It's gonna be a happy ending. There's going to be no more hitting ... no more calling you abusive names ... Yeah, we're going to have a quarrel now and again--who doesn't? But the hitting is gone, the alcohol is gone ... I just want to get it back to how it should have been in the first place. That's what I want. 
Temuera Morrison: And that's what everyone wants. And it seems more achievable, now that family violence is out in the open.

While viewers may very well question the sincerity of Robert's transformation, nothing in the accompanying visual imagery or scripted conclusion contests this 'happily ever after' denouement. Indeed, rather than interrogating the notion that marriage necessarily constitutes a safe haven for women, the selection and arrangement of interview material, the discursive content of the script, and decisions regarding editing and framing —which come together to portray an apparently idyllic family grouping--all potentially serve in these documentaries to reaffirm the hegemonic interests of violent men. While these texts are to some extent multivocal in terms of allowing for the articulation of competing discursive understandings of domestic violence, the mode of textual construction works to either subsume alternate voices entirely beneath the dominant perspective, or else to recuperate them for hegemonic purposes.

For example, the heavy reliance in all three documentaries (and especially Picking Up the Pieces) on personal testimony and 'survivor speech' means that the primary emphasis remains on individual women's subjective realities and experiences of suffering, on explaining and rationalizing their actions and beliefs, and on exploring catalysts for change in their lives. Such emphasis not only has the potential to bolster dominant constructions of women as perennial objects of voyeuristic gaze and essentially vulnerable to victimization (Alcoff and Gray 1993), but as we have shown, risks affirming victim-blaming discourses. As Alcoff and Gray (1993) note, this strategy also tends to displace feminist critiques of male power, along with the attempt to acknowledge 
men's collective responsibility as the primary perpetrators of serious violence within the home.

\section{Conclusion: recuperating domestic violence}

While the three police 'Family Violence' documentaries (and, indeed, the wider media campaign itself) should perhaps be seen as a commendable attempt to bring domestic violence into the public domain and to model the capacity of violent men to change, the discursive construction of the issue within these texts remains highly problematic. This is a matter for ongoing concern, given the international interest in this campaign and the continued use of the documentaries in certain counselling and educational settings in New Zealand.

Not surprisingly, given the close involvement of police in instigating and overseeing the production of campaign materials, all three documentaries affirm and idealise the police and judicial response to violence in the home. A variety of discursive manoeuvres and narrative devices ensure that any implied or overt criticism of police inaction or judicial ineffectiveness is quickly silenced - usually by consigning any apparent failings to the past, whilst simultaneously affirming the current effectiveness of both police and the courts in dealing with violence in the home. In this way, these documentaries effectively recuperate feminist critiques of the patriarchal state; particularly feminist criticisms of the resistance victims frequently encounter from police and the justice system when seeking protection from men's violence and abuse.

The utilization of individual case studies and the reliance on personal testimony and 'survivor discourse' in all three documentaries thus raises a number of important 
questions regarding the ability of mainstream media representations to challenge patriarchal violence, the extent to which women's experience may be exploited as a media commodity, and the potential for personal testimony and survivor speech to be recuperated for hegemonic interests in the process of its textual (re)presentation. We would argue that the manner in which these documentaries were constructed affirms patriarchal hegemonic interests; since ultimately, these texts privilege discourses that effectively silence the roles of both abusers and society in perpetuating male violence. The resulting (and progressively more intensive) narrative focus on individual victims-engaged in talking about their suffering or seeking help, leaving or not leaving-marginalizes socio-political critique and leaves the issues of both institutional failure and male abuse of power essentially unchallenged. In particular, we highlight the way in which the focus of attention in all three texts is "deflect[ed] . . . away from the harshness of the verdict than men are responsible for their own violence" (Howe 1998: 38). Given that in 1999, 91 percent of those charged with some form of physical abuse were male (Christopher Clark 2001: 2), the potential societal impact of such textual evasions is especially troubling.

In part, the discursive manoeuvres identified here can be considered an outcome of the need to maintain the interest of, rather than alienate, male viewers--not only in an effort to secure maximum audience ratings for the documentaries, but also in an attempt to communicate with potential perpetrators of, and witnesses to, domestic violence. But they are also indicative of a society that is ultimately unable to reflect on the support that it lends to the continuing violent abuse of women and children, even as it recognises that the costs of that violence go well beyond the price paid by individual victims. 


\section{Notes}

1 Carter (1998) does, however, challenge this assertion. Her analysis of UK tabloid newspapers found that accounts of 'battering' feature more frequently than reports of 'stranger rape'. However, as Carter stresses, reports of domestic violence are highly routinised in terms of being positioned as 'interesting but not greatly important news' and receive very brief coverage in comparison with more 'extraordinary' crimes such as murder.

2 As discussed further below, the use of the descriptor 'family violence' is problematic as its use potentially deflects responsibility away from the primary perpetrators of serious physical violence in the home--namely, men--and thus has significant political implications.

3 New Zealand On Air is the government body that funds locally made television and radio productions. Additional sponsorship for the Police Family Violence campaign came from Carter Holt Harvey Limited (a wood and pulp manufacturer) and Telecom New Zealand.

4 Such a rationale is somewhat ironic, given that so much of the content of these programmes seems to focus on women's experiences of abuse, in ways that potentially deflect responsibility away from offenders. 


\section{References}

Alcoff, Linda and Laura Gray. 1993. "Survivor Discourse: Transgression or Recuperation.” Signs: Journal of Women in Culture and Society 18(2): 260-290.

Benedict, Helen. 1992. Virgin or Vamp: How the Press Covers Sex Crimes. New York: Oxford University Press.

Berns, Nancy. 1999. “'My Problem and How I Solved It’: Domestic Violence in Women's Magazines.” The Sociological Quarterly 40(1): 85-108.

Cameron, Deborah and Elizabeth Fraser. 1987. The Lust to Kill: A Feminist Investigation of Sexual Murder. New York: New York University Press.

Caputi, Jane. 1992. "The Sexual Politics of Murder," in Pauline Bart and Eileen Moran (eds.) Violence Against Women: The Bloody Footprints, pp. 5-25. Newbury Park: Sage.

Caringella-MacDonald, Susan. 1998. "The Relative Visibility of Rape Cases in National Popular Magazines.” Violence Against Women 4(1): 62-80.

Carmody, Dianne Cyr. 1998. "Mixed Messages: Images of Domestic Violence on 'Reality' Television,” in Mark Fishman and Gary Cavender (eds.) Entertaining Crime: Television Reality Programs, pp. 158-174. New York: Aldine de Gruyter. Carter, Cynthia. 1998. "When the 'Extraordinary' Becomes 'Ordinary',” in Cynthia Carter, Gill Branston and Stuart Allen (eds.) News, Gender and Power, pp. 219-232. London and New York: Routledge.

Consalvo, Mia. 1998. "Hegemony, Domestic Violence, and Cops: A Critique of Concordance." Journal of Popular Film and Television 26(2): 62-70. 
Clark, Christopher. 2001. The Age of Physical Abuse Victims and the Sentence Imposed on their Abusers. Wellington: Ministry of Justice.

Corner, John, Kay Richardson and Natalie Fenton. 1990. Nuclear Reactions: Form and

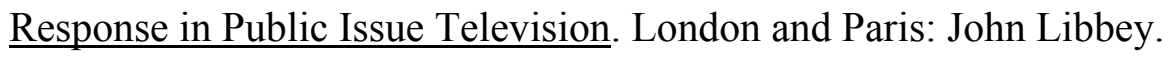

Cuklanz, Lisa M. 2000. Rape on Prime Time: Television, Masculinity, and Sexual Violence. Philadelphia: University of Pennsylvania Press.

Davies, Miranda. 1994. Women and Violence: Realities and Responses World Wide. London: Zed Books.

Department of Social Welfare. 1996. New Zealand Government Statement of Policy on Family Violence. Wellington: Department of Social Welfare.

Dobash, Rebecca Emerson and Russell P. Dobash. 1979. Violence Against Wives. New York: Free Press.

Dobash, Rebecca Emerson and Russell P. Dobash. 1998. "Violent Men and Violent Contexts," in Rebecca Emerson Dobash and Russell P. Dobash (eds.) Rethinking Violence Against Women, pp. 141-168. Thousand Oaks: Sage.

Fairclough, Norman. 1989. Language and Power. London and New York: Longman. Foucault Michel. 1972. The Archaeology of Knowledge. A. M. Sheridan Smith (trans.). London: Tavistock Publications.

Foucault Michel. 1980. Power-Knowledge: Selected Interviews and Other Writings, 1972-1977. Colin Gordon (ed.). Colin Gordon, Leo Marshall, John Mepham, and Kate Soper (trans.). Brighton, Sussex: Harvester Press.

Gelles, Richard J. and Murray A. Straus. 1988. Intimate Violence: The Causes and Consequences of Abuse in the American Family. New York: Simon and Schuster. 
Gelles, Richard. 1999. 'Male Offenders: Our Understanding From the Data,' in James O’Neil and Michele Harway (eds.) What Causes Men's Violence Against Women?, pp. 36-48. Thousand Oaks: Sage.

Gordon, Margaret and Stephanie Riger. 1989. The Female Fear. New York: Free Press. Howe, Adrian. 1998. "Notes from a 'War' Zone: Reporting Domestic/Family/Home/ Epidemic (Men's) Violence," in Adrian Howe (ed.) Sexed Crime in the News, pp. 2955. Sydney: The Federation Press.

Kaufman, Glenda Kantor and Murray A. Straus. 1990. "The 'Drunken Bum' Theory of Wife Beating," in Murray A. Straus \& Richard J. Gelles (eds.) Physical Violence in American Families, pp. 31-56. New Brunswick: Transaction Publishers.

Kozol, Wendy. 1995. "Fracturing Domesticity: Media, Nationalism, and the Question of Feminist Influence." Signs: Journal of Women in Culture and Society 20(3): 646-667. Laclau, Ernesto and Chantal Mouffe. 1985. Hegemony and Socialist Strategy: Towards a Radical Democratic Politics. Winston Moore and Paul Cammack (trans.). London: Verso.

Macdonald, Myra. 1998. “Politicizing the Personal: Women's Voices in British Television Documentaries," in Cynthia Carter, Gill Branston and Stuart Allen (eds.) News, Gender and Power, pp. 105-120. London and New York: Routledge. McDonald, Mary. 1999. "Unnecessary Roughness: Gender and Racial Politics in Domestic Violence Media Events." Sociology of Sports Journal 16: 111-133. Marin, Amy and Nancy Felipe Russo. 1999. "Feminist Perspectives on Male Violence Against Women: Critiquing O'Neil and Harway's Model,'” in James O’Neil and 
Michele Harway (eds.) What Causes Men's Violence Against Women? pp. 18-35.

Thousand Oaks: Sage.

McLaughlan, Lisa. 1998. "Gender, Privacy and Publicity in 'Media Event Space'," in

Cynthia Carter, Gill Branston and Stuart Allen (eds.) News, Gender and Power, pp.

71-90. London and New York: Routledge.

Meyers, Marian. 1997. News Coverage of Violence Against Women: Engendering

Blame. Thousand Oaks: Sage.

Nichols, Bill. 1991. Representing Reality: Issues and Concepts in Documentary. Bloomington: Indiana University Press.

Not Just a Domestic (video recording). 1994. Carol Archie (dir.). John Harris (prod.).

Not Just a Domestic: The Update (video recording). 1994. John Harris (dir.). John Harris (prod.).

Once Were Warriors (video recording). 1994. Lee Tamahori (dir.). Robin Scholes (prod.).

O’Neill, Damian. 1998. “A Post-Structuralist Review of the Theoretical Literature Surrounding Wife Abuse." Violence Against Women 4(4): 456-490.

O’Neill, Damian. 2000. "Domestically Violent Men Speak: A Post-Structuralist Critique.” New Zealand Sociology 15(1): 1-29.

Philo, Greg. 1990. Seeing and Believing: The Influence of Television. London and New York: Routledge.

Picking Up the Pieces (video recording). 1996. Wayne Tourell (dir.). Mark Casey (prod.). Snively, Susan. 1994. The New Zealand Economic Cost of Family Violence. Wellington: Coopers and Lybrand/Family Violence Unit. 
Soothill, Keith and Sylvia Walby. 1991. Sex Crime in the News. New York: Routledge.

Straus, Murray and Richard Gelles. 1990. Physical Violence in American Families. New Brunswick: Transaction Publishers.

van Zoonen, Liesbet. 1991. “A Tyranny of Intimacy? Women, Femininity and Television News," in Peter Dahlgren and Collin Sparks (eds.) Communication and Citizenship, pp. 217-236. London: Routledge.

Walker, Lenore. 1989. Terrifying Love: Why Battered Women Kill and How Society

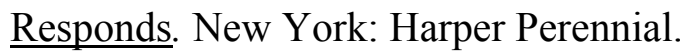

Weaver, C. Kay. 1998. "Crimewatch UK: Keeping Women off the Streets," in Cynthia Carter, Gill Branston and Stuart Allen (eds.) News, Gender and Power, pp. 248-262. London and New York: Routledge.

Weaver, C. Kay and Carolyn Michelle. 1999. "Public Communication Compromised: The Impact of Corporate Sponsorship on a Pro-Social Media Campaign.” Australian Journal of Communication 26(3): 83-97.

Weaver, C. Kay, Cynthia Carter and Elizabeth Stanko. 2000. "The Female Body at Risk: Media, Sexual Violence and the Gendering of Public Environments," in Stuart Allan, Barbara Adam and Cynthia Carter (eds.) Environmental Risks and the Media, pp.171183. London and New York: Routledge.

Weedon, Chris. 1987. Feminist Practice and Poststructuralist Theory. Oxford: Basil Blackwell.

Wykes, Maggie. 1998. “A Family Affair: The British Press, Sex and the Wests,” in Cynthia Carter, Gill Branston and Stuart Allen (eds.) News, Gender and Power, pp. 233-247. London and New York: Routledge. 
Zubretsky, Theresa M. and Karla M. Digirolamo. 1996. "The False Connection Between Adult Domestic Violence and Alcohol,” in Albert R. Roberts (ed.) Helping Battered Women, pp. 222-228. Second Edition. New York: Oxford University Press. 